\title{
SPORY W LITERATURZE NIEMIECKIEJ O NIEZGODNE Z PRAWDA ZEZNANIA OSKARŻONEGO O POPEŁNIENIE PRZESTĘPSTWA
}

I. Przedmiotem niniejszego artykułu jest próba odpowiedzi na pytanie, czy oskarżony w niemieckim procesie karnym, zeznając fałszywie i tym samym naruszając prawa innych osób, może liczyć na uniknięcie odpowiedzialności karnej. Aby udzielić na nie odpowiedzi, dokonam przeglądu najważniejszych stanowisk wyrażonych $\mathrm{w}$ tym zakresie w niemieckiej literaturze przedmiotu (a nawet szerzej - niemieckojęzycznej). Ze względu na niebudzący wątpliwości fakt, że wskazany problem wywołuje spory na gruncie polskiej nauki prawa karnego, warto - celem znalezienia dodatkowych argumentów za określonym ujęciem - literaturę tę przeanalizować.

W prawie niemieckim ${ }^{1}$ pytanie o kontratyp ,,prawa do kłamstwa” oskarżonego sprowokowało żywą dyskusję. Toczyła się ona już podczas tworzenia kodeksu postępowania karnego z 1877 r. i dotyczyła w pierwszej kolejności kwestii ciążącego na oskarżonym obowiązku wyjaśniania prawdy. Dopiero w kontekście tego obowiązku pojawiła się w niemieckiej literaturze przedmiotu refleksja nad zastosowaniem kontratypu dla fałszywych wyjaśnień, którymi oskarżony narusza prawa osób trzecich. W czasie obrad komisji parlamentarnej nad projektem tego kodeksu zwracano uwagę na to, że oskarżony nie powinien być całkowicie odebrany sędziemu jako środek dociekania prawdy ${ }^{2}$, podkreślając przy tym, że państwo nie ma prawa zmuszać oskarżonego do wyjaśniania prawdy ${ }^{3}$. Znajomością realiów procesowych wykazał się wówczas poseł

${ }^{1} \mathrm{~W}$ artykule zatosowano następujące skróty: BGH - Bundesgerichtshof (Sąd Najwyższy Niemiecki), BGE - Bundesgericht Entscheidungen (Orzeczenia Sądu Najwyższego Szwajcarii), BVerfG - Bundesverfassungsgericht, JA - ,Juristische Ausbildung”, JW - ,Juristische Wochenschrift”, DJZ - „Deutsche Juristen Zeitung”, FS - Festschrift, GG - Grundgesetz (Konstytucja Niemiec z 23 maja 1949 r.), RGZ - „Entscheidungen des Reichsgerichts in Zivilsachen”, RMGE - „Reichmilitargericht Entscheidungen”, ZPO - Zivilprozeßordnung, ZStW - ,Zeitschrift für die gesamte Strafrechtwissenschaft”.

${ }^{2} \mathrm{Na}$ co zwracał uwagę zwłaszcza poseł Herz-Entfoldt-Rloß, wskazując: „,Sowie man das Streben nach Wahrheit auflöse in die Wahrnehmung widerstreitender Interessen, so raube man ihm seines Wertes". Zob. C. Hahn Die gesamten Materiellen zu den Reichs-Justizgesetzen, Dritter Band, Erste Abtheilung, Berlin 1880, s. 703-707.

${ }^{3}$ Rzecznikiem tego stanowiska był przede wszystkim poseł Wolfsfona. Zob. C. Hahn, op. cit., s. 704-705. W tym miejscu należy zwrócić uwagę, że juryści niemieccy posługują się w tym kontekście różnymi terminami. Chodzi tutaj po pierwsze o „,Vernehmung”, po drugie - „Wahrheitspflicht”, dalej „Recht auf Lüge”, którym w języku polskim odpowiadają terminy ,,przesłuchanie”, ,obowiązek wyjaśniania prawdy” oraz ,,prawo do kłamstwa”. Tak więc przykładowo ostatnie zdanie artykułu Fezera (G. Fezer, Recht auf Lüge?, w: FS Johannes Wessel, Heidelberg 1993, s. 684, o którym niżej, brzmi: 
Herz, który podniósł, że rezygnacja w projekcie z możliwości śledczego przesłuchiwania oskarżonego jest niewystarczająca, gdyż w praktyce nadal zdarzają się sędziowie, którzy maja w zwyczaju inkwizycyjne przesłuchiwanie oskarżonego ${ }^{4}$.

Z wypowiedzi tych wyraźnie wynika, że prawnicy tworzący niemiecki kodeks postępowania karnego byli dość niezdecydowani. Można by powiedzieć, że byli oni zawieszeni pomiędzy starym modelem procesu opartego na zasadzie śledczości a ujęciem procesu opierającego się na zasadzie skargowości. Aby zrozumieć powody tego stanu rzeczy, poczynić należy kilka uwag o charakterze historycznym.

II. W średniowiecznym procesie kanonicznym, toczącym się przed sądami kościelnymi, obowiązek wyjaśnienia prawdy przez oskarżonego stał się asumptem do wykrystalizowania się pewnej odmienności stanowisk. Według pierwszego poglądu, którego rzecznikiem był już Jan Chryzostom ${ }^{5}$, a później też Gracjan ${ }^{6}$, podsądny miał bezwarunkowy obowiązek wyjaśniania całej prawdy (warto jednak wspomnieć, że w porównaniu z procesem świeckim proces kanoniczny charakteryzował się rozbudowanymi gwarancjami dla oskarżonego ${ }^{7}$ ). Drugie natomiast stanowisko, którego rzecznikiem był w pierwszej kolejności Tomasz z Akwinu ${ }^{8}$, ograniczało ten obowiązek tylko co do okoliczności znanych sędziemu ${ }^{9}$. Stąd też $\mathrm{w}$ przekonaniu niemieckich procesualistów genezy pełniejszego ukształtowania się wyobrażenia, że oskarżony jest od tego obowiązku zwolniony, doszukiwać się należy raczej w procesie angielskim ${ }^{10}$, tym bardziej że zasada śledczości przenikała jeszcze Constitutio criminalis Carolina ${ }^{11}$.

„Dem Fehlen der Wahrheitspflicht entspricht ein Recht auf Lüge”. Jednakże w tym kontekście należy dodać, że terminowi prawo do kłamstwa nadaje się na gruncie nauki niemieckiej różne znaczenia.

${ }^{4}$ Jego wypowiedź ma jednoznaczną wymowę: „Der Entwurf enthalte keine Vorschrift, daß der Verhörsrichter den Angeschuldigten inquiriren oder auch nur zur Wahrheitsangabe ermahnen solle, aber diese negative Haltung des Entwurfs sei ungenügend, wenn man erwäge, daß man zur Zeit Untersuchungsrichter habe, welche an das Inquriren gewöhnt seien" (zob. C. Hahn, op. cit., s. 704-705). $\mathrm{Z}$ związku z tym zdaje się on przychylać do koncepcji uregulowania tej kwestii w przeciwnym kierunku.

${ }^{5}$ Pogląd Jana Chryzostoma jest w niniejszym opracowaniu przywoływany za pośrednictwem jego omówienia przez K. Rogalla, w jego dysertacji: Der Beschuldigte als Mittel gegen sich selbst, Berlin 1977, s. 70 i n.

${ }^{6}$ Decr. II caus XXXIII, Quest. III, capt. 87.

${ }^{7}$ Czego przejawem było chociażby to, że w razie uniewinnienia oskarżanego donosiciel odpowiadał jak oszczerca. Zwraca się zresztą na to uwagę również w doktrynie polskiej, zob. A. Dziadzio, Powszechna historia prawa, Warszawa 2008, s. 435.

${ }^{8}$ Summa theologica, II-II, Questio LXIX Art. I.

${ }^{9}$ Chociażby per famam. Oznaczało to, że nie miał on obowiązku wyjaśniania prawdy w sensie ujawniania nowych okoliczności, co było zresztą o tyle istotne, że wobec wprowadzenia procesu ex officio mere przez Inocentego III podczas Soboru Laterańskiego IV w 1215 r. problem ten uzyskał także wymiar etyczny. Zob. Qualiter et cuando, nr 2, Decretales Gregorii IX 5.1.24; E. Friedberg, Corpus iuris canonici, t. 1-2, Lipsk 1879-1881 (wznowione Graz 1959).

${ }^{10}$ Wskazuje się tutaj na przykład procesu Johna Lilbourna po jego rehabilitacji i zmianie wyroku w 1648 r., co zapoczątkowało tradycję odmowy zeznań. Zob. też T. Salmona, S. Emlyna, A Collection of State-Trials and Proceedings, upon High-Treason, and Other Crimes and Misdemours from the Reign of King Edward VI to the Present Time", t. 7, Thomas Salmon, Sollom Emlyn, 1735, s. 337, gdzie zawarte sa akta procesu.

${ }^{11}$ A jej integralnymi elementami było traktowanie oskarżonego jako obiektu, który ma obowiązek wyjaśniać prawdę, oraz nałożenie na niego samego obowiązku wyjaśnień - i to pomimo że CCC sama 
Natomiast na samym niemieckim gruncie ważnym momentem $\mathrm{w}$ ewolucji poglądów na ten temat zdaje się $\mathrm{w}$ pierwszej kolejności debata prowadzona, począwszy od lat trzydziestych XIX w. Pojawiają się wtedy pierwsze głosy postulujące zwolnienie oskarżonego $\mathrm{z}$ obowiązku wyjaśniania prawdy w procesie $^{12}$, co jest pewnego rodzaju papierkiem lakmusowym, świadczacym o przejściu do koncepcji procesu skargowego ${ }^{13}$. Postulat ten został następnie zrealizowany w kodeksach postępowania karnego na szczeblu krajów wchodzących w skład Związku Niemieckiego - pierwszym przykładem zdaje się regulacja Braunschweigu ${ }^{14}$. Natomiast nieco inaczej kształtowała się sytuacja w Szwajcarii ${ }^{15}$.

W tym kontekście wyrażony został pogląd ${ }^{16}$, że istnieje ścisły związek pomiędzy położeniem obywatela $\mathrm{w}$ państwie a pozycją oskarżonego $\mathrm{w}$ procesie, nałożonymi na niego obowiązkami a przysługującymi mu gwarancjami procesowymi. Wydaje się, że choć nie można odmówić temu stwierdzeniu częściowej słuszności, jest to uogólnienie zbyt daleko idące, gdyż pozycja ta jest uzależniona także od wielu innych czynników, chociażby tak trywialnych jak to, czy państwo znajduje się stanie wojny ${ }^{17}$, czy też przyjętego modelu kształcenia prawników i stanowienia prawa.

Po uchwaleniu jednolitego dla zjednoczonego przez Bismarcka państwa niemieckiego kodeksu postępowania karnego problem ten, w związku ze wspomnianym wymijającym stanowiskiem komisji opracowującej projekt, stał się zarzewiem gorącej dyskusji prawników. U progu XX w. wypowiadał się w tej kwestii K. Binding ${ }^{18}$; twierdził on, że obowiązek wyjaśniania prawdy przez oskarżonego jest ukształtowany $\mathrm{w}$ procesie jako norma niezabezpieczona żadna

w sobie nie zawierała norm karzących za kłamstwo, z wyjątkiem może art. 107 oraz 110 (krzywoprzysięstwo oraz fałszywe oskarżenie).

${ }^{12}$ Wskazać tutaj należy przykładowo na opracowanie C. J. A. Mittelmeyera, Die Lehre vom Beweise im deutschen Strafprozesse, Darmstadt 1834. Innym dobrym przykładem jest późniejszy referat wygłoszony podczas II Dnia Prawników Niemieckich przez L. von Stemanna z 1861 r. Zob. materiały z tego zjazdu opublikowane jako Verhandlungen des zweiten deutschen Juristentages, Zweiter Band, Berlin 1861. Cytat za: K. Rogall, op. cit., s. 101.

${ }^{13}$ Oczywiście można by mówić o powrocie do zasady skargowości, która występowała w procesie starogermańskim przed rokiem 1235, zob. E. Schmidt, Einführung in die Geschichte der deutschen Strafrechtspflege, Göttingen 1995 (unveränderter Nachdruck), s. 86.

${ }^{14}$ Chodzi tutaj o Kodeks postępowania karnego z 1849 r. Jego tekst można znaleźć w: Die größeren Justizorganisationsgesetze und die Reform des deutschen Strafverfahrens, Göttingen 1846, s. 55-118. Po nim nastąpił szereg dalszych regulacji, a tę samą myśl odnaleźć można w uzasadnieniu austriackiego k.p.k., zob. Die österreichische Strafprozessordnung vom. 23. Mai 1873, Wien 1874, s. 202.

${ }^{15}$ Gdzie przyjmowane rozwiązania zależą od poszczególnych kantonów. Tak więc do $1968 \mathrm{r}$. obowiązek wyjaśniania prawdy zawarty był w art. 91 k.p.k. kantonu Glarus oraz w art. 171 kodeksu obowiązującego we Freiburgu. Krytyczne omówienie tych regulacji zawarte jest w pracy H. Schreidera, Die Stellung des Beschuldigten im Hinblick auf die Aussage nach formellem und materiellem Recht, Zürich 1968, s. 5 i n.

${ }^{16}$ H. Schreider, op. cit., s. 31.

${ }_{17}$ Podczas którego naturalnie szybko zapomina się o respektowaniu przyznanych podsądnemu praw.

${ }_{18}$ Zob. K. Binding, Die Wahreheitspflicht im Prozesse DJZ 1909, szp. 161-167. Artykuł ten jest fragmentem polemiki ze R. Schmidtem (Die Lüge im Prozess, DJZ 1909, szp. 39-45) oraz z K. Hellwigiem (stanowisko w „Woche” 40, 1908, s. 1715), który opowiada się za stanowiskiem tego drugiego. Zaznaczyć należy, że asumptem do podjęcia tej debaty było istnienie obowiązku mówienia prawdy w niemieckim procesie cywilnym (który obecnie statuuje $§ 138$ (1) ZPO: „Die Parteien haben ihre Erklärungen über tatsächliche Umstände vollständig und der Wahrheit gemäß abzugeben”). 
sankcją - lex imperfecta. Jej walor bierze się stąd, że umożliwia ona wprawnemu przewodniczącemu uzyskanie od oskarżonego niezbędnych informacji ${ }^{19}$. Był to jednak pogląd, który nie spotkał się z aprobatą Sądu Wojskowego Rzeszy ${ }^{20}$.

W okresie republiki weimarskiej doszło do scementowania przeciwstawnych stanowisk, nie brakowało jednak nadal naukowców opowiadających się za istnieniem obowiązku wyjaśniania prawdy, spoczywającym na oskarżonym w procesie ${ }^{21}$.

III. Zupełnie inaczej kształtowała się debata w okresie nazistowskim. Jej cechą charakterystyczną było dążenie do przeobrażenia procesu w oparciu o zasadę śledczości, wprowadzenia ustawowego obowiązku wyjaśniania prawdy przez oskarżonego czy zniesienia antagonizmu pomiędzy stronami, zwłaszcza poprzez zredukowanie roli adwokata do roli obrońcy prawa. Świetną ilustracją tych zamierzeń jest praca $R$. Thierfeldera ${ }^{22}$, w której przedstawiono utopijna koncepcję, że oskarżony walczy po stronie państwa przeciwko własnemu czynowi, czy propozycja U. Stocka ${ }^{23}$, aby wprowadzić kary za kłamstwo przy poważniejszych przestępstwach. Do tego chóru zaliczyć należy także wcześniejszą wypowiedź $H$. Henkla ${ }^{24}$, który podkreślał, że obowiązek składania prawdziwych wyjaśnień ciążyć może tylko winnemu, a wspólnota oczekuje od oskarżonego pojmowania własnego czynu i skruchy; poza tym wprowadzenie takiego obowiązku prowadzić może jedynie do afirmacji osobowości oskarżonego $^{25}$. Przeciwko temu podniosły się jednak głosy sprzeciwu ${ }^{26}$. Nadmienić należy, że koncepcje te nie ograniczyły się jedynie do wypowiedzi w literaturze przedmiotu, lecz przybrały realniejszy wyraz w pracach komisji opracowującej propozycje zmian kodeksu postępowania karnego w latach trzydziestych. $\mathrm{Na}$ szczęście te utopijne zmiany nie stały się nigdy obowiązującym prawem ${ }^{27}$.

${ }^{19}$ Wskazać należy w tym kontekście, że nie wszystkie argumenty podnoszone przez autora moga przemawiać również do współczesnego jurysty, jak chociażby ten, że istnieć musi symetria obowiązków pomiędzy sądem a oskarżonym.

${ }^{20}$ RMGE 8, 207, aprobująco odnosi się do tej tezy OLG Hamm NJW 1965, 62. Podstawą tego sprzeciwu jest odwołanie się do prawa natury.

${ }^{21}$ Rzecznikiem takiego stanowiska był chociażby Graf zu Dohna, który pisał wprost: „Es sei ihm unerfindlich, wie jemand aus der Begehung des Verbrechens sollte das Recht herleiten dürfen, das Gericht zu belügen”, zob. jego stanowisko zawarte w podręczniku Das Strafprozessrecht, Berlin 1929, s. 107. Przeciwko temu opowiadał się m.in. L. Kohlrausch, Die Untersuchungshaft I. Festnahme und Untersuchngshaft (Beitrag), JW 1925, s. 1441.

${ }^{22}$ R. Thierfelder, Normativ und Wert in der Strafrechtwissenschaft unserer Tage, Mohr 1936.

${ }^{23}$ Zob. U. Stock, Die Strafe als Dienst am Volk, Mohr 1933.

${ }^{24}$ H. Henkel, Die Gestalt des künftigen Strafverfahrens, DJZ 1930, s. 527-538.

25 Zob. ibidem, s. 536.

${ }^{26}$ W szczególności charyzmatycznej obrony cywilizowanego procesu podjął się H. Engelhard, Die Vernehmung des Beschuldigten, ZstW 1939, s. 335-362, pisząc, że pojednanie się oskarżonego w przypadku ataku wspólnoty jest bardzo mało prawdopodobne, nadto przytacza on aprobująco pogląd R. Freislera, że podniesienie moralnego obowiązku zeznawania prawdy nie wpłynie w żadnym zakresie na zmniejszenie liczby kłamstw (Zob. R. Freisler, Grundzüge des kommenden Strafverfahrensrechts, DS 1935, s. 233). Również E. Wolf (,ZZeitschrift der Akademie für Deutches Recht” 1937/178) uważał, że dla zatwardziałych przestępców nawet wprowadzenie kar kłamstwa nie spełniałoby swojej funkcji generalno-prewencyjnej. Trudno odmówić temu poglądowi słuszności. Do tej grupy zaliczyć należy także Graf zu Dohna, który podnosił (zob. Deutches Strafrecht, 1935, s. 261), że gwarancje procesowe obejmować muszą wszystkich oskarżonych, a nie tylko towarzyszy partyjnych.

${ }^{27}$ Chodzi tutaj przykładowo o materiały z obrad dużej i małej komisji do reformy prawa karnego procesowego (Beratungen der Kleinen und Großen Strafprozeßkommission), która w latach 1936-1939 
IV. Problem niezgodnych z prawdą zeznań oskarżonego stał się ponownie przedmiotem dyskusji w literaturze niemieckiej po zakończeniu II wojny światowej. Już w latach pięćdziesiątych znaleźć można odrębną wypowiedź poświęconą temu zagadnieniu ${ }^{28}$, w której $\mathrm{H}$. Pfenniger, odrzucając argument, że obowiązek stawienia się w sądzie musi być połączony z obowiązkiem złożenia prawdziwych wyjaśnień, zaznacza, iż samo sprowadzenie obrony oskarżonego do prawa do milczenia byłoby dla niego privilegium odiosum ${ }^{29}$.

Dyskusja przybrała znacząco na sile w latach sześćdziesiątych i siedemdziesiątych. Mimo to nie zostały wtedy ukształtowane nowe stanowiska, chociaż podnoszono nowe argumenty. Dla A. Castringiusa ${ }^{30}$ pytanie o prawo do kłamstwa oskarżonego jest $\mathrm{w}$ samych przepisach postępowania karnego nierozstrzygnięte, stąd też odwołuje się on do niemieckiej konstytucji. Chodzi tutaj o normę wysłowioną $\mathrm{w}$ art. $2 \mathrm{I} \mathrm{GG}^{31}$, której przypisuje on centralne znaczenie $\mathrm{w}$ całym systemie prawnym. Zagwarantowana $\mathrm{w}$ nim obywatelowi przestrzeń wolności znajduje swoja granicę w normie moralnej - odwołuje się on do G. Radbrucha ${ }^{32}$ i tłumaczy, że chodzi tu o poczucie przyzwoitości wszystkich cnotliwie i sprawiedliwie myślących ludzi ${ }^{33}$. Stąd też zakazuje on oskarżonemu składania fałszywych wyjaśnień, a jedyny wyjątek czyni na rzecz pytań niemających związku z postępowaniem, które to pytania moga poniżyć oskarżonego.

Wspomnieć należy w tym miejscu pracę, która powstała na gruncie prawa szwajcarskiego, a dokładniej: na gruncie prawa kantonalnego Zürichu. H. Wal$\operatorname{der}^{34}$ jest świadomy, że szwajcarski Sąd Najwyższy wypowiedział się przeciwko

sporządziła 3 projekty kodeksu postępowania karnego. Miały one różny stosunek do obowiązku wyjaśniania prawdy przez oskarżonego. Wedle najwcześniejszego z nich § 141 ust. 2: „Der Beschuldigte erhält die Gelegenheit, Verdachtsgründe, zu widerlegen, Tatsachen geltend zu machen, die zu seinen Gunsten sprechen, und Beweismittel für seine Angaben zu nennen". Natomiast w projekcie z 27 lutego 1936 r. zawarte zostało postanowienie, że: „Die Vernehmung des Beschuldigten dient der Ermittlung der Wahrheit. Der Beschuldigte ist darauf hinzuweisen, daß von ihm eine wahrheitstreue Aussage erwartet wird und daß Unwarheiten im Falle der Verurteilung zu einer höheren Strafe fuhren können", zob. W. Schubert (wyd.), Entwürfe zu einer Strafverfahrensordnung und einer Friedens und Schiedsrichterordnung (1936-1939), Berlin-New York 1991, s. 39, 245 i 318-319.

${ }^{28}$ Chodzi tutaj o stanowisko H. Pfennigera, prof. z Zürichu, zamieszczona w: Die Wahrheitspflicht des Beschuldigten im Strafverfahren, w: FS Rittler, Aalen 1957, s. 335-373. Nie brak w niej obszernych odwołań do stanowisk przyjmowanych w prawie niemieckim.

${ }^{29}$ Zresztą nie miałoby ono żadnej doniosłości praktycznej, gdyż w ciągu 14 lat pracy jako prokurator w Zürichu zanotował zaledwie jeden taki przypadek. Trafna zdaje się również uwaga, że z punktu widzenia psychologii nierealne jest oczekiwanie, że sędzia, który jest tylko człowiekiem, zignoruje milczenie, co podniesione już zostało przez A. Harmanna na gruncie prawa amerykańskiego (zob. Die Strafrechtspflege in Amerika, Berlin 1906, s. 231 i n.

${ }^{30}$ A. Castringius, Leugnen des Beschuldigten im Strafprozess, Hamburg 1965, s. 4-10, 19-27, 40-62 i 67-72. Wskazuje on zarazem, że źródłem kłamstwa jest instynkt samozachowawczy.

${ }^{31}$ Który stanowi, że każdy ma prawo do rozwoju swojej osobowości: ,(1) Jeder hat das Recht auf die freie Entfaltung seiner Persönlichkeit, soweit er nicht die Rechte anderer verletzt und nicht gegen die verfassungsmäßige Ordnung oder das Sittengesetz verstößt”.

${ }^{32}$ G. Radbruch, Einführung in die Rechtswissenschaft, wyd. 8, Leipzig 1929. Zupełnie na marginesie zauważyć należy, że w tej samej książce filozof zauważa, iż celem rozwoju prawa karnego nie jest jego poprawa, tylko zastąpienie przez coś lepszego (zob. ibidem, s. 115).

${ }^{33} \mathrm{Z}$ tym zbiega się poniekąd formuła, która posłużył się Sąd Najwyższy Niemiecki w wyroku RGZ 48, 114, 124 (BGHZ 10, 228, 232).

${ }^{34}$ H. Walder, Die Vernehmung des Beschuldigten, Zürich 1965. 
prawu do kłamstwa ${ }^{35}$, on sam jest głęboko przekonany, że brak wyłączenia odpowiedzialności za naruszenie norm prawa materialnego w oparciu o jakiśs kontratyp prawa do kłamstwa ${ }^{36}$. Utrzymanie obowiązku mówienia prawdy jest jednak konieczne nie tylko dlatego, żeby zapobiec degradacji procesu do niegodnej walki stron, lecz także dlatego, że wypływa on $\mathrm{z}$ norm prawnych ${ }^{37}$.

Wspomnieć należy krótko o stanowisku J. Wesselsa ${ }^{38}$. Symptomatyczne jest to, że rozpoczyna on swe rozważania od części historycznej, która jest preludium do stanowczej kontry wobec stwierdzenia H. Henkelsa ${ }^{39}$, że obowiązek pokuty rozpoczyna się $\mathrm{z}$ chwilą wszczęcia postępowania. Jest to bowiem $\mathrm{w}$ jego przekonaniu sprzeczne z zasadą domniemania niewinności ${ }^{40}$. Obrazuje to chyba zmaganie prawników dekady lat sześćdziesiątych, aby usunąć wszelkie pozostałości poglądów z czasów nazizmu.

Nie sposób w tym kontekście nie wspomnieć o pracy K. Höry ${ }^{41}$, który zalicza się do autorów odrzucających kontratyp prawa do kłamstwa. Jego rozważania należy uznać za istotny wkład do toczącej się debaty. W pierwszej kolejności podkreśla on, że milczenie ustawodawcy $\mathrm{w}$ tej kwestii nie ma znaczenia ${ }^{42}$. Przyjęty przez niego sposób argumentacji wykazuje znaczną oryginalność. Wychodzi on bowiem od stwierdzenia, że obowiązek ustalenia prawdy jest niejako celem postępowania karnego i że gdy oskarżony dobrowolnie składa wyjaśnienia, nie korzystając $\mathrm{z}$ prawa do milczenia, muszą dla niego obowiązywać te same reguły co do innych środków dowodowych ${ }^{43}$.

Jak widać, dyskusja w prawie niemieckim w tym okresie była niezwykle intensywna. Dowodem na to niech będzie kolejna wypowiedź autorstwa K. Rogalla ${ }^{44}$, który to odwołuje się do pierwszeństwa normy chroniącej osobowość człowieka ${ }^{45}$ przed zbyt bezwzględnym dociekaniem prawdy, co jest też, w jego przekonaniu, zgodne $\mathrm{z}$ prawem natury ${ }^{46}$. Jako ciekawostkę

${ }^{35}$ BGE 74 IV s. 54, przyp. 62.

${ }^{36}$ Zob. H. Walder, op. cit., s. 75.

${ }^{37}$ Chodzi w tym miejscu zwłaszcza o brzmienie ówczesnego $§ 152$ k.p.k. obowiązującego w Zürichu, który to nakazywał pokazanie oskarżonemu protokołów zeznań świadków, przy przesłuchaniu których oskarżony nie uczestniczy. Gdyby na oskarżonym nie ciążył obowiązek składania prawdziwych wyjaśnień, naruszenie tego przepisu i wynikającej z niej normy prawnej nie byłoby, zdaniem $\mathrm{H}$. Waldera, równoznaczne z naruszeniem praw strony.

38 J. Wessels, Schweigen und Leugnen im Strafverfahren, ,Juristische Schulung” 1966, s. 169-176.

${ }^{39}$ Wyrażonego w pierwszym wydaniu podręcznika Strafverfahrensrecht. Ein Studienbuch, Stuttgart 1953, s. 49 i n.

${ }^{40}$ Powołuje się on w tym względzie na art. 6 II Europejskiej konwencji praw człowieka.

${ }^{41}$ K. Höra, Wahrheitspflicht und Schweigebefugnis des Beschuldigten, Zwenkau bei Leipzig 1970.

${ }^{42}$ Gdyż „Das Gesetz sei kluger als Gesetzgeber”. A więc wedle starej maksymy ustawa jest mądrzejsza od ustawodawcy.

${ }^{43}$ Poza tym stwierdza on, że osobowe źródła informacji są całkowicie nieprzydatne jako źródło dociekania prawdy, gdy nie ciąży na nich obowiązek mówienia prawdy. Zob. K. Höra, op. cit., s. 80. Jest to oczywiście pogląd dyskusyjny, gdyż w zestawieniu z innymi dowodami kłamstwo może je nieraz uwiarygodnić.

${ }^{44}$ K. Rogall, Der Beschuldigte als Mittel gegen sich selbst, Berlin 1977.

${ }^{45}$ Zakodowanej w art. 2 I, 1 I, 19 II GG.

${ }^{46}$ Odwołanie do prawa natury rozumieć należy w ten sposób, że oskarżony w przypadku ataku wspólnoty i zagrożenia odpowiedzialnością karną, na zasadzie instynktu samozachowawczego broni się wszelkimi dostępnymi środkami, w tym również kłamstwem. 
przytoczyć należy jego postulat, aby spór ten przenieść w świat baśni, gdyż jest on w znacznej mierze zbędny ${ }^{47}$.

V. Kolejna dekada przyniosła pewne osłabienie zapalczywości prowadzonej debaty. Pojawił się jednak głos P. Rießa ${ }^{48}$, który to po dokonaniu klasyfikacji stanowisk, odrzucił moralny obowiązek zeznawania prawdy ${ }^{49}$. Wskazuje bowiem, że podstawą procesu musi być swoboda wyjaśnień ${ }^{50}$, a z niej samej nie sposób wyprowadzić prawa do kłamstwa, które miałoby być kontratypem wobec norm prawa karnego materialnego, byłoby to bowiem zbyt daleko idące. Jakkolwiek dostrzega on samo sedno problemu, to głównym zarzutem, jaki można postawić autorowi, jest to, że niedostatecznie objaśnia swoje stanowiska ${ }^{51}$.

W latach dziewięćdziesiątych $\mathrm{w}$ dalszym ciagu w tej kwesti pojawiały się jedynie nieliczne wypowiedzi. Dobrym przykładem zdaje się w tym kontekście krótkie opracowanie G. Fezera ${ }^{52}$. Na początku swoich rozważań stawia on tezę, że milczenie komisji opracowującej projekt postępowania karnego rozumieć należy w ten sposób, że nie chciała ona jedynie ustawowo zakorzenić obowiązku składania wyjaśnień zgodnych z prawda ${ }^{53}$. Szczególnie nieprzekonujący jest dla niego argument, że prawo do kłamstwa nie może istnieć, gdyż brak o nim pouczenia ${ }^{54}$. Jednak nadaje on terminowi ,prawo do kłamstwa” takie znaczenie, że jego granice są wytyczane normami prawa karnego materialnego ${ }^{55}$. Czytając to solidne, krótkie opracowanie, odnosi się wrażenie, że autor zamierzał podsumować w nim stan dyskusji i rozwiązać problem. Jednakże już niebawem pojawiły się nowe głosy i nowi protagoniści polemiki.

Widać to zwłaszcza na początku nowego wieku. Ważnym głosem jest w tej mierze monografia poświęcona zasadzie nemo tenetur $\mathrm{R}$. Torki ${ }^{56}$. Po dokonaniu przeglądu reprezentowanych w doktrynie stanowisk, podejmuje się on odważnej próby określenia prawa do kłamstwa jako prawa zakorzenionego konstytucyjnie, które to nie podlega modyfikacji. Podstawą tych rozważań jest odwołanie

${ }^{47}$ Co mieli poniekąd zauważyć już naziści. Zob. K. Rogall, op.cit., s. 67-103, 139-147.

48 P. Rieß, Die Vernehmung des Beschuldigten im Strafprozess, JA 1980, s. 293-301.

${ }^{49}$ Wskazuje on przy okazji na stosunek napięcia pomiędzy dwiema funkcjami wyjaśnień oskarżonego, które służą obronie i poznaniu prawdy. Zob. P. Rieß, op. cit., s. 296-297. Pod tym względem jest to zbieżne z konstatacjami polskiej doktryny. Zob. w tym względzie chociażby pracę L. Hochberga, Wyjaśnienia oskarżonego $w$ procesie karnym i ich wartość dowodowa, Warszawa 1962, s. 28-32.

${ }^{50}$ Odwołując się w tej mierze do stanowiska BGH St, 14, 364.

${ }^{51}$ Co dobitnie widać na przykładzie jego stwierdzenia, że w pewnych sytuacjach kłamstwo jest godne pochwały (,Es sind Fälle denkbar, in denen eine Lüge billigenswert sein kann”, a więc stwierdzenie, że dają się pomyśleć przypadki, kiedy kłamstwo może być godne aprobaty, moralne), bez podania jednak jakiegokolwiek przykładu, Zob. P. Rieß, op. cit., s. 296-297.

${ }^{52}$ G. Fezer, op. cit., s. 663-684.

53 Zob. ibidem, s. 671.

${ }^{54}$ Rozprawia się z tym, wskazując inne sytuacje, kiedy nie poucza się oskarżonego o przysługujących mu prawach, jak chociażby $\S 168 \mathrm{c}$ - obecność oskarżonego przy przeprowadzaniu dowodów poza rozprawą główną, czy prawo do wyboru adwokata - § 140. G. Fezer zauważa, że nie ma podstaw do wprowadzenia takiego pouczenia w oparciu o zasadę sprawiedliwego procesu. Obszerne wyliczanie regulacji niemieckiego k.p.k. - idem, op. cit., s. 680.

${ }^{55}$ Zob. ibidem, s. 671-678. Jest to więc nie tyle wąskie rozumienie tego pojęcia, ile nawet odrzucenie koncepcji kontratypu prawa do kłamstwa.

${ }^{56}$ R. Torka, Nachtat und Nemo-tenetur, Berlin 2000. 
się do zasady państwa prawnego i zasady ochrony godności ludzkiej, które to zasady nakazują minimalizację liczby błędnych wyroków wydawanych w sprawach karnych ${ }^{57}$. Tak więc postawienie dodatkowego zarzutu za kłamstwa $\mathrm{w}$ postępowaniu oskarżonemu, prowadzące do jego podwójnego pokonania prawem, nie ma racji bytu ${ }^{58}$, tym bardziej że wyjaśnienia oskarżonego nie maja dla właściwego przebiegu i wyniku procesu takiego znaczenia, jak chociażby zeznania świadków czy opinia biegłych. Wskazać należy nadto, że wkładem naukowca $\mathrm{z}$ Passau jest próba wpisania prawa do kłamstwa w rozszerzona zasadę nemo tenetur, przy jednoczesnej konstatacji, że kłamstwo bez naruszenia praw osób trzecich jest prawie nie do pomyślenia ${ }^{59}$. Stąd też jest on, co do zasady, przeciwnikiem pojmowania go jako kontratypu z jednym kardynalnym wyjątkiem: wtedy gdy naruszenie praw osób trzecich jest obiektywnym warunkiem sine qua non uniknięcia skazania, tak że osoba trzecia musi w tym wypadku znieść naruszenie swojego dobra prawnego ${ }^{60}$. W tym wyjątkowym przypadku opowiada się za uznaniem go za okoliczność wyłączającą bezprawność takiego czynu ${ }^{61}$.

Z kolei J. Gruber ${ }^{62}$ dochodzi do wniosku, że prawo do kłamstwa oskarżonego da się również odkodować $\mathrm{z}$ norm o randze konstytucyjnej. Jako podstawę wskazuje on art. 5 I GG 1 półzdanie ${ }^{63}$, który chroni prawo do wolności wypowiedzi, jeżeli mają one za przedmiot sądy wartościujące, oraz art. 2 I GG ${ }^{64}$, który znajduje zastosowanie w wypadku wypowiedzi niepołączonych z takimi sądami. Regulacje te byłyby jednak pozbawione wszelkiego znaczenia, gdyby nie były zabezpieczone przez konieczność ich wysłuchania przez sąd ${ }^{65}$. Szczególne znaczenie $\mathrm{w}$ tym kontekście przypada $\mathrm{w}$ ujęciu J. Grubera normie zawartej w art. $103 \mathrm{GG}^{66}$, która chroni jednak wypowiedzi związane z przed-

${ }^{57}$ Zob. R. Torka, op. cit., s. 72-85 i 134-140.

${ }^{58}$ Inaczej jest natomiast ze świadkami czy biegłymi, pełnią oni bowiem inną rolę w procesie. Ich kłamstwo jest wtedy samoistną treścią wyroku.

59 Zob. R. Torka, op. cit., s. 135.

${ }^{60}$ Zob. szczegóły ibidem, s. 164-183. Wskazuje przy tym, że przy wyznaczaniu granic warto kierować się na $§ 35$ niem. k.k., w którym zakodowany został w niemieckim prawie karnym stan wyższej konieczności wyłączający winę. Jest to związane z tym, że prawie każde kłamstwo dotyka osoby trzeciej, co powoduje konieczność analizy, kiedy jest to conditio sine qua non bezkarności. Warto tutaj zwrócić uwagę na inny jeszcze przykład podawany przez R. Torkę, a mianowicie: kazus spermy (der Sperma Fall), gdzie w trakcie seksu oralnego będącego wynikiem zgwałcenia oskarżony posunąć się może jedynie do pomówienia, że seks miał miejsce dobrowolnie, ale w żadnym wypadku do naruszenia integralności cielesnej ofiary. Zob. R. Torka, op. cit., s. 172. Podobne dylematy ilustruje Prahlerei Fall, rozstrzygnięty wyrokiem 1 StR 811/93.

${ }^{61}$ Zob. R. Torka, op. cit., s. 227.

${ }^{62}$ Jest on autorem ujęcia monograficznego poświęconego tej kwestii - J. T. Gruber, Die Lüge des Beschuldigten im Strafverfahren, Baden-Baden 2008. Jego praca powinna być zarazem postrzegana jako stanowcza polemika z twierdzeniami R. Torki.

${ }^{63}$ Pełne zdanie tego przepisu brzmi: ,,Jeder hat das Recht, seine Meinung in Wort, Schrift und Bild frei $\mathrm{zu}$ äußern und $\mathrm{zu}$ verbreiten und sich aus allgemein zugänglichen Quellen ungehindert $\mathrm{zu}$ unterrichten".

${ }^{64}$ Przypomnieć należy w tym miejscu raz jeszcze jego treść ,(1) Jeder hat das Recht auf die freie Entfaltung seiner Persönlichkeit, soweit er nicht die Rechte anderer verletzt und nicht gegen die verfassungsmäßige Ordnung oder das Sittengesetz verstößt”.

${ }^{65}$ Zob. J. Gruber, op. cit., s. 217.

${ }^{66}$ Którego treścią jest przyznanie oskarżonemu prawa do wysłuchania sądowego - ,,(1) Vor Gericht hat jedermann Anspruch auf rechtliches Gehör" - takie ujęcie jest zgodne z dominującym poglądem 
miotem procesu i wysłowione w zakresie przysługującego oskarżonemu prawa do wypowiedzi.

Wszystko to jednak prowadzi do konkluzji, że oskarżony kłamać może, o tyle jednak, o ile nie narusza swoim postępowaniem norm prawa materialnego ${ }^{67}$. Nie można bowiem rozstrzygającego znaczenia przypisywać braku jednoznacznego zakazu kłamstwa w normach prawa procesowego ${ }^{68}$. Tak więc autor najnowszego stanowiska wybiera $\mathrm{w}$ tej mierze rozwiązanie salomonowe: chociaż posługuje się nominalnym pojęciem prawa do kłamstwa, nadaje mu węższe, przyjmowane chociażby przez G. Fezera ${ }^{69}$, znaczenie.

VI. Podsumowując, należy zauważyć, że dyskusja w prawie niemieckim jest daleka od zakończenia. Jeżeliby przyjąć za miarodajny obraz jej obecnego stanu stanowiska wyrażane w podstawowych współczesnych komentarzach, to rysuje się przewaga stanowiska umiarkowanego ${ }^{70}$.

W opracowaniu z konieczności przedstawiono zaledwie kilka stanowisk, gdyż dokładne przedstawienie wszystkich poglądów i argumentów nie jest naturalnie możliwe ${ }^{71}$. Wobec stylu uprawiania niemieckiej nauki, która

w orzecznictwie, zob. chociażby wyroki BVerfGE 107, 395, 407, BVerfG 61, 82, 104, 75, 192, 200. Rolę tej normy prawnej określa J. Gruber jako zabezpieczenie istniejących praw wolnościowych w postępowaniu.

${ }^{67} \mathrm{~W}$ tym kontekście zauważyć należy, że chodzić tutaj może o popełnienie przestępstw określonych w $§ 130$ I Nr. 2 oraz 130 III, 145d, 164, 185-189, 258, 263. Jest to zarazem ujęcie dość rozpowszechnione w orzecznictwie, o czym dobrze świadczy szereg wyroków (np. BayObLG NJW 1984, 2302, OLG Celle NJW 1964, 733, OLG Karlsruhe, MDR 1992, 1166, BayObLG JR 1986, 28, OLG Karlsruhe NStZ 1990, 282, BGH StV 1996, 259, BGHSt 46, 36, 45, a w odniesieniu do postępowania podatkowego np. BHGSt 47, 8, 14, BGH StV 2002, 203, przy czym najczęściej chyba posługuje się orzecznictwo kategorią fałszywego oskarżenia pod warunkiem braku związku z prowadzonym postępowaniem karnym - zob. zwłaszcza wyrok OLG Brandenburg NJW 1997, 141, 142).

${ }^{68}$ Posługuje się on w tej mierze przykładem, że z braku zakazu stosowania przemocy fizycznej do ochrony swojej wolności osobistej nie można wnioskować o przyzwoleniu do stosowania przemocy wobec prokuratora. Zob. R. Torka, op. cit., s. 128.

${ }^{69}$ Zob. przyp. 52.

70 Tak przykładowo autor odrębnego komentarza poświęconego prawu dowodowemu (Beweisrecht der StPO, Spezialkommentar, Ulrich Eisenberg, München 2011, s. 183) stoi na stanowisku, że ewentualne kłamstwo oskarżonego nie ma skutków procesowych, brak jest jednak czegoś takiego jak kontratyp prawa do kłamstwa. Wskazuje on jednak na linię orzeczniczą Niemieckiego Sądu Najwyższego, wedle której dopuszczalne jest z wnioskowanie z kłamstwa oskarżonego o jego stosunku do prawa (,,rechtsfeindliche Gesinnung” BGH 1, 103, BGH „Neue Zeitschrift für Strafrecht” 81, 257 i przez to zaostrzanie wymiaru kary. Podobnie M. Lemke (Heidelberger Kommentar zur Strafprozessordnung, wyd. 4, 2009 § 136, Rn. 27), pisząc, iż o ile nie ma on prawa do kłamstwa i może być karany w przypadku naruszenia norm prawa karnego materialnego, o tyle nie ma on obowiązku mówienia prawdy. Dalej H. Diemer zauważa, że (Karlsruher Kommentar zur Strafprozessordnung: StPO, wyd. 6, 2008, § 136 Rn. 20) oskarżonego nie obciąża obowiązek mówienie prawdy, jeżeli nie narusza norm prawa karnego. W tym samym duchu również E.-W. Hanack, w: StPO Großkommentar-Löwe Rosenbarg, wyd. 24, 1985, z powołaniem się na orzecznictwo, zwłaszcza na BayObLGSt 1964, 147, Walther w: Anwaltskommentar StPO, wyd. 2, $\$ 136$ Rn. 29, oraz G. Pfeiffer w: StPO Kommentar, § 136 Rn. 4. W żadnym z tych komentarzy nie podejmuje się jednak szerszego uzasadnienia czy prób argumentacji. Chyba jedynym odstępstwem pod tym względem jest pogląd H. H. Lescha (KMR Kommentar zur Strafprozzessordnung, wyd. 1999, § 136, Rn. 49), że jeżeli oskarżony nie jest zobowiązany do mówienia prawdy, musi być uprawniony do kłamania: ,Wer nicht zur Wahrheit verpfichtet ist, ist zur Lüge nicht berechtigt, tertium non datur". U podstaw takiego myślenia kryje się założenie, że system prawny operuje „,binarnym” systemem zakazów i nakazów. Nie jest to jednak chyba założenie trafne.

${ }^{71}$ F. Liszt, Die falsche Aussage vor Gericht oder öffentlicher Behörde nach deutschem und österreichischem Recht, Graz 1877; F. Krunicki, Das Leugnen als Schärfungsgrund, DJZ 1909, 537-538; 
w pierwszej kolejności posługuje się argumentacją historyczną ${ }^{72}$ oraz stosunkowo częstymi odwołaniami do ustawy zasadniczej, milczenie ustawodawcy w uzasadnieniu projektu kodeksu postępowania karnego okazało się nadzwyczaj kłopotliwe. Zarazem jednak otworzyło pole do prowadzenia szerokiej debaty o wysokim poziomie argumentacyjnym. Jej najwyższe natężenie zdaje się przypadać na lata sześćdziesiąte i siedemdziesiąte ${ }^{73}$. Wydaje się, że było to związane $\mathrm{z}$ przeprowadzoną wówczas nowelizacją przepisów rozdziału 10 kodeksu $^{74}$. Ostatnim ważnym ogniwem tej dyskusji jest monografia J. Grubera.

Nikt poważnie nie kwestionuje już tego, że na gruncie niemieckiego kodeksu postępowania karnego oskarżony może kłamać. Pogląd jednak, że te kłamstwa sięgać mogą tak daleko, aby wyłączać bezprawność czynów stypizowanych $\mathrm{w}$ prawie karnym materialnym, jest w absolutnej mniejszości ${ }^{75}$. Jest to pod tym względem konkluzja zbieżna z tą, do której dochodzą polscy juryści, chociaż zupełnie inną drogą ${ }^{76}$ i oznacza ni mniej, ni więcej niż odrzucenie kontratypu prawa do obrony. Zarazem jednak uznaje się, że takie kłamliwe wyjaśnienia mogą wpływać na zaostrzenie kary w ramach jej ustawowego wymiaru, do czego wystarczająca podstawą zdaje się treść $§ 46$ Abs. 2 StGB $^{77}$. Takie też ujęcie przyjmuje się w orzecznictwie ${ }^{78}$, co powoduje, że nie jest to całkowicie

M. Liepmann, Die Psychologie der Vernehmung des Angeklagten, ZstW 1924, s. 647-683; H. Rüping, Zur Mitwirkung Pflicht des Beschuldigten und Angeklagten, ,Juristische Rundschau” 1974, s. 135-140; wczesną pracę poświęconą prawu austriackiemu: H. Müller-Dietz, Die Stellung des Beschuldigten im Strafprozess, ZstW 1981, s. 1177-1270; H. H. Lesch, Inqusition und rechtliches Gehör in der Beschuldigtenvernehmung, ZstW 99, s. 624-646; K. Volk, Wahrheit und materielles Recht im Strafprozess, Konstantiner Universitätsreden 1988, s. 1-30; M. Nothelfer, Die Freiheit von Selbstbezichtigungszwang, Verfassungsrechtliche Grundlagen und eingfachgesetzliche Ausformungen, Heidelberg 1989; N. Bosch, Aspekte des nemo-tenetur Grundsatzes aus verfassungsrechtlicher und strafprozessualer Sicht, Berlin 1998.

${ }^{72}$ Dobrze kontrastuje z tym opublikowany po niemiecku szkic A. Wąska, Zur Frage des Rechts des Angeklagten auf Lüge, w: FS Nishihara 1998, s. 294-306.

${ }^{73}$ Co zdaniem J. Gerlacha (Die Vernehmung des Beschuldigten und der Schutz vor Selbstbeschuldigung im deutschen und anglo-amerikanischen Strafverfahren. Ein entwicklungeschichtliche Bilanz, w: FS Hanack, Berlin-New York 1999, s. 117-145) jest związane z tym, że dopiero wtedy Sąd Najwyższy Niemiecki pokusił się o pełne wdrożenie zasady nemo-tenetur se ipsum accusere, tak jak uczynione to zostało w USA (zob. orzeczenia BGHSt 22, 170,175, inaczej BGHSt 20, 281 oraz Mirand vs. Arizona, Griffin vs. California 380 US. 609). Pod tym względem jego stanowisko w J. von Gerlach, op. cit., s. 117-143, przyp. 95. Co ciekawe, również w Polsce w tym okresie zaprezentowano szereg nowych stanowisk.

${ }^{74}$ Wprowadzoną ustawą StPäG z 19 grudnia 1964 r., zwłaszcza $§ 136$ StPO otrzymał nieco inne brzmienie, gdyż stanowi się, że oskarżonemu należy wskazać, iż ma swobodę składnia wyjaśnień.

${ }^{75}$ Wydaje się, że w nowszej literaturze jego zwolennikiem jest zwłaszcza R. Torka, który - co należy przypomnieć - przyjmuje go tylko wtedy, gdy jest on warunkiem sine qua non wyłączenia karalności. Zob. wyżej, przyp. 60 .

${ }^{76}$ Wskazać tutaj można zwłaszcza na artykuł Ł. Pohla (Składanie wyjaśnień przez oskarżonego w polskim postepowaniu karnym - szkic teoretycznoprawny, „Prokuratura i Prawo” 2007, z. 2), w którym autor, posługując się warsztatem teoretycznoprawnym, wybiera ścieżkę argumentacji całkowicie oryginalną na tle swoich niemieckich kolegów.

${ }^{77}$ Chodzi tutaj w szczególności o przepis ten in fine, który stanowi, że przy wymiarze kary uwzględnia się ,,sein Verhalten nach der Tat, besonders sein Bemühen, den Schaden wiedergutzumachen, sowie das Bemühen des Täters, einen Ausgleich mit dem Verletzten zu erreichen”.

${ }^{78}$ Czego dobrym przykładem zdają się wyroki 4 StR 893/53 (NJW 1954, 1416). Zauważyć należy, że czasami dokonuje się to pośrednio, a więc poprzez wnioskowanie z kłamstw oskarżonego o wrogim wobec prawa usposobieniu (,Rechtsfeindliche Gesinnung”), czego przykładem może być chociażby wyrok BGH 1, 103; BGH NstZ 81, 257. Nie brakuje tutaj jednak stanowisk odmiennych (np. BGH JZ 1980, 335). 
zharmonizowane czy konsekwentne $\mathrm{z}$ postulatem przyznania oskarżonemu swobody składania fałszywych wyjaśnień, a tym bardziej - „,prawa do kłamstwa” w węższym zakresie. Na koniec powtórzyć należy jeszcze jedno istotne spostrzeżenie terminologiczne: juryści niemieccy nadają pojęciu prawa do kłamstwa różne znaczenia.

W świetle przedstawionej dyskusji można więc uznać, że stan obecnie prowadzonej debaty u naszych zachodnich sąsiadów nie jest zbyt odległy od stanu dyskusji w Polsce, co powoduje, że można tam poszukiwać raczej argumentów niż gotowych rozwiązań.

mgr Marcin Byczyk

Uniwersytet im. Adama Mickiewicza w Poznaniu

\author{
DISPUTES IN GERMAN LITERATURE REGARDING \\ THE UNTRUE EVIDENCE PROVIDED BY A PERSON ACCUSED \\ OF AN ALLEGED CRIME
}

\begin{abstract}
Summary
An attempt is being made to outline the historical evolution of the debate in the German doctrine concerning the right of the accused to lie. The considerations begin with a claim that this issue was not solved during the codification work carried out in the nineteenth century, and had consequently given rise to an ample discussion among German lawyers, that resulted in the formulation of three major positions. According to the first one, the accused in the penal process should be obliged to confess the truth. The opposite view stressed that the accused could resort to lying as long as he did not infringe the rights of others. And only recently (R. Torka) has originated a conception that under certain circumstances, namely when infringing the rights of the others is the sine que non condition for the escaping of criminal responsibility, a so-called right to lie of the accused has to be taken into account. The arguments brought to life by German lawyers may also considerably enrich the debate over the same issue in Poland.
\end{abstract}


Copyright of Journal of Law, Economics and Sociology is the property of Faculty of Law and Administration of Adam Mickiewicz University in Poznan and its content may not be copied or emailed to multiple sites or posted to a listserv without the copyright holder's express written permission. However, users may print, download, or email articles for individual use.

Właścicielem praw autorskich do „Ruchu Prawniczego, Ekonomicznego i Socjologicznego” jest Wydział Prawa i Administracji Uniwersytetu im. Adama Mickiewicza w Poznaniu. Zawartość czasopisma nie może być kopiowana, przesyłana do innych stron internetowych bądź zamieszczana na blogach bez pisemnej zgody wydawcy. Niemniej artykuły można drukować, kopiować lub przesyłać w formie elektronicznej na własny użytek. 